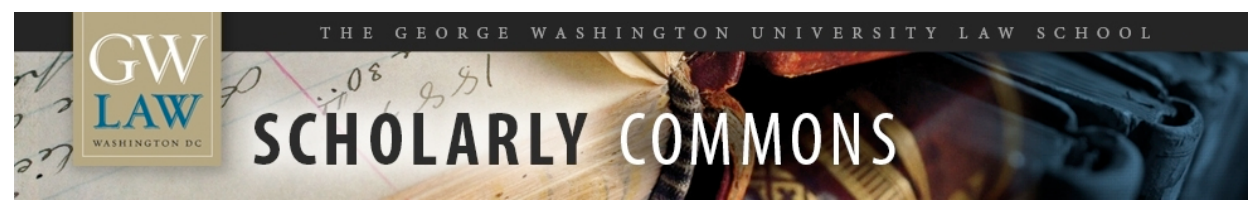

Policy Brief: The OCC's Repeated Failures to Comply with the Dodd-Frank Act and Other Legal Authorities Governing the Scope of Preemption for National Banks and Federal Savings

Associations

Arthur E. Wilmarth Jr. 


\title{
Policy Brief: The OCC's Repeated Failures to Comply with the Dodd-Frank Act and Other Legal Authorities Governing the Scope of Preemption for National Banks and Federal Savings Associations
}

\author{
Arthur E. Wilmarth, Jr.* \\ November 8, 2021
}

\section{Introduction}

The Dodd-Frank Wall Street Reform and Consumer Protection Act of 2010 (DoddFrank $)^{1}$ established a new framework for determining whether state consumer financial laws apply to national banks and federal savings associations, or whether those laws are preempted under the National Bank Act (NBA) and the Home Owners' Loan Act (HOLA). The key provisions of Dodd-Frank's preemption framework are codified in 12 U.S.C. § 25b (Section 25b). As shown below, the Office of the Comptroller of the Currency (OCC) has issued several regulations, policies, and interpretations that do not comply with Section $25 \mathrm{~b}$ and other legal authorities governing the scope of preemption under the NBA and HOLA. The OCC should promptly rescind or revise those measures to achieve compliance with Section $25 \mathrm{~b}$ and other applicable authorities.

\section{Analysis}

\section{Dodd-Frank establishes a new framework governing preemption of "state consumer financial laws" under the NBA and HOLA.}

Section $25 \mathrm{~b}$ establishes standards and procedures for determining whether "state consumer financial laws" apply to national banks or are preempted by federal law. Section $25 \mathrm{~b}$ was enacted as Section 1044 of Dodd-Frank. ${ }^{2}$ Section 25b(a)(2) defines "state consumer financial law" as a state law that "directly and specifically regulates the manner, content, or terms and conditions of any financial transaction (as may be authorized for national banks to engage in), or any account related thereto, with respect to a consumer."

Under Section 25b(b)(1), a state consumer financial law is preempted "only if" (A) the state law has "a discriminatory effect on national banks," or (B) the state law "prevents or significantly interferes with the exercise by the national bank of its powers," or (C) the state law is preempted by a federal statute other than the NBA. ${ }^{4}$ Section $25 b(b)(1)(B)$ codifies the "prevent or significantly interfere" standard for preemption that was established by the Supreme Court's 1996 decision in Barnett Bank of Marion County, N.A. v. Nelson. ${ }^{5}$

\footnotetext{
*Professor Emeritus of Law, George Washington University Law School.

${ }^{1}$ Pub. L. No. 111-203, 124 Stat. 1376 (2010).

${ }^{2}$ Id. $\S 1044,124$ Stat. 2014 (codified at 12 U.S.C. $\$ 25 b$ ).

${ }^{3} 12$ U.S.C. $\$ 25 b(a)(2)$.

${ }^{4} 12$ U.S.C. $\$ 25 b(b)(1)$.

${ }^{5} 517$ U.S. 25, 33 (1996). For court decisions and legislative history sources affirming that Section 25b(b)(1)(B) incorporates and codifies the "prevent or significantly interfere" preemption standard established by Barnett Bank, see Lusnak v. Bank of America, N.A., 883 F.3d 1185, 1188, 1191-94 (9th Cir.), cert. denied, 139 S. Ct. 567 (2018); Clark v. Bank of America, N.A., 2020 WL 902457 at *3-*4 (D. Md., Feb. 24, 2020); Hymes v. Bank of America,
} 
Under Section 1046 of Dodd-Frank, codified at 12 U.S.C. $§ 1465(a)$, Section 25b’s preemption framework for national banks also governs federal savings associations. ${ }^{6}$ Thus, state consumer financial laws apply to both national banks and federal savings associations unless they create an impermissible conflict with federal law under the preemption standards set forth in Section $25 b(b)(1){ }^{7}$ In addition, Sections $25 b(b)(4)$ and $1465(b)$ make clear that preemption under NBA and HOLA is governed by principles of conflict preemption, not field preemption. Those statutes provide that the NBA and HOLA "do[] not occupy the field in any area of state law."

Section $25 \mathrm{~b}(\mathrm{c})$ requires the OCC to demonstrate, with regard to each of its preemption rules and orders, that "substantial evidence, made on the record of the proceeding," supports the OCC's "specific finding" of preemption in accordance with the "legal standard of . . Barnett Bank." Under Sections 25b(b)(1)(B) and 25b(b)(3), the OCC must act on a "case-by-case basis" when it issues a preemption rule or order. To satisfy the "case-by-case" requirement, the OCC must consider "the impact of a particular State consumer financial law on any national bank that is subject to that law, or the law of any other State with substantially equivalent terms." Additionally, the OCC must "first consult with the Bureau of Consumer Financial Protection and take the views of the Bureau into account" when the OCC makes a "case-by-case" determination. $^{10}$

Under Section $25 \mathrm{~b}(\mathrm{~b})(5)(\mathrm{A})$, courts reviewing preemption determinations by the OCC must "assess the validity of such determinations, depending upon the thoroughness evident in the consideration of the agency, the validity of the reasoning of the agency, the consistency with other valid determinations made by the agency, and other factors which the court finds persuasive and relevant to its decision." 11 Section $25 \mathrm{~b}(\mathrm{~b})(5)(\mathrm{A})$ incorporates the Skidmore standard of limited deference for judicial review of OCC preemption determinations, as defined by the Supreme Court in Skidmore v. Swift \& Co. ${ }^{12}$ A reviewing court gives much less deference to an agency's ruling under Skidmore than it would under the Chevron doctrine. Under

N.A., 408 F. Supp. 3d 171, 179, 184 (E.D.N.Y. 2019); H.R. Rep. No. 111-517, at 875 (2010) (Conf. Rep.), reprinted in 2010 U.S.C.C.A.N. 722, 731; S. Rep. No. 111-176, at 175-76 (2010).

${ }^{6}$ Pub. L. No. 111-203, $§ 1046,124$ Stat. 2017 (2010) (codified at 12 U.S.C. $§ 1465(a)$ ).

712 U.S.C. $\$ \S 25 b(b)(1) \&$ 1465(a). See Jared Elosta, "Dynamic Federalism and Consumer Financial Protection: How the Dodd-Frank Act Changes the Preemption Debate," 89 North Carolina Law Review 1273, 1276-77, 1298 (2011); Arthur E. Wilmarth, Jr., "The Dodd-Frank Act's Expansion of State Authority to Protect Consumers of Financial Services," 36 Journal of Corporation Law 893, 925-30 (2011) [hereinafter Wilmarth, "Dodd-Frank”], available at http://ssrn.com/abstract $=1891970$.

812 U.S.C. $\$ \S 25 \mathrm{~b}(\mathrm{~b})(4), 1465(\mathrm{~b})$; see also Wilmarth, "Dodd-Frank," supra note 7, at 932.

912 U.S.C. $\$ 25 b(c)$.

${ }^{10} 12$ U.S.C. $\$ \S 25 b(\mathrm{~b})(1)(\mathrm{B}), 25 \mathrm{~b}(\mathrm{~b})(3)(\mathrm{A}) \&(\mathrm{~B})$; see also Lusnak, 883 F.3d at 1192, 1194; Elosta, supra note 7, at 1300-01; Wilmarth, "Dodd-Frank," supra note 7, at 931-32.

1112 U.S.C. $\$ 25 b(b)(5)(A)$.

12323 U.S. 134 (1944). For court decisions affirming that Section 25b(b)(5)(A) establishes a standard of Skidmore deference for the OCC's preemption determinations, see Lusnak, 883 F.3d at 1192-93; Hymes, 408 F. Supp. 3d at 190-92; Clark, supra note 5, at *4-*5. 
Skidmore, the weight to be given by a court to an agency's ruling depends on "all those factors which give it power to persuade, if lacking power to control."13

Section $25 \mathrm{~b}$ includes three overlapping provisions that broadly uphold the application of state laws to subsidiaries, affiliates and agents of national banks. First, Section $25 \mathrm{~b}(\mathrm{~b})(2)$ declares that the NBA and 12 U.S.C. $\$ 371$ "do not preempt, annul, or affect the applicability of any State law to any subsidiary or affiliate of a national bank (other than a subsidiary or affiliate that is chartered as a national bank)."14 Thus, Section $25 b(b)(2)$ makes clear that federal laws governing national banks do not affect the application of all types of state laws - including state consumer financial laws and general state laws - to nonbank subsidiaries and affiliates of national banks. Section 25b(b)(2) overrules Watters v. Wachovia Bank, N.A., ${ }^{15}$ which held that the NBA preempted the application of state mortgage lending laws to a state-chartered operating subsidiary of a national bank in the same way that the NBA preempted the application of such laws to the parent national bank. ${ }^{16}$

Second, Section $25 b(e)$ provides that "[n]otwithstanding any provision of [the NBA and 12 U.S.C. $§ 371]$, a State consumer financial law shall apply to a subsidiary or affiliate of a national bank (other than a subsidiary or affiliate that is chartered as a national bank) to the same extent that the State consumer financial law applies to any person, corporation, or other entity subject to such State law."17 Section 25b(e) covers much of the same ground as Section $25 b(b)(2)$, except that Section $25 b$ (e) focuses on nondiscrimination (i.e., the equal application of state laws to all affected persons) and applies only to state consumer financial laws instead of all state laws. If a state consumer financial law applies on a nondiscriminatory basis to any person, corporation, or other entity, the same law will apply equally to a nonbank subsidiary or affiliate of a national bank.

Third, Section $25 \mathrm{~b}(\mathrm{~h})$ provides that "[n] provision of [the NBA or 12 U.S.C. $\S 371$ ] shall be construed as preempting, annulling, altering, or affecting the applicability of State law to any subsidiary, affiliate, or agent of a national bank (other than a subsidiary, affiliate, or agent that is chartered as a national bank)." 18 The non-preemptive language of subsection (h) closely resembles the text of paragraph (b)(2) and encompasses all types of state laws. However, subsection (h) goes further by declaring that the NBA does not preempt the application of state laws to agents of national banks. Subsection (h) thereby overrules pre-Dodd-Frank court decisions holding that agents of national banks enjoyed a preemptive immunity from state laws comparable to the preemption granted to operating subsidiaries by Watters. ${ }^{19}$ The foregoing

\footnotetext{
${ }^{13}$ United States v. Mead Corp., 533 U.S. 218, 228 (2001) (quoting Skidmore, 323 U.S. at 140). For court decisions affirming that the OCC's preemption determinations receive only Skidmore deference rather than Chevron deference, see Lusnak, 883 F.3d at 1192-93; Hymes, 408 F. Supp. 3d at 190-91; Clark, supra note 5, at *5.

1412 U.S.C. $\$ 25 b(b)(2)$.

15550 U.S. 1 (2007).

${ }^{16}$ Id. at 15-21. See Miss. Dept. of Revenue v. Pikco Fin., Inc., 97 So.3d 1203, 1209 n.7 (Miss. 2012) (explaining that Dodd-Frank "overturned judicial precedent like Watters and rescinded preemption of state law as to national bank subsidiaries and affiliates"); Wilmarth, "Dodd-Frank," supra note 7, at 934-35 (reaching the same conclusions).

1712 U.S.C. $\S 25 b(e)$.

1812 U.S.C. $\S 25 \mathrm{~b}(\mathrm{~h})$.

${ }^{19}$ See Wilmarth, "Dodd-Frank," supra note 7, at 935, 935n.318 (citing Pacific Capital Bank, N.A. v. Connecticut, 542 F.3d 341 (2d Cir. 2008); SPGGC, LLC v. Ayotte, 488 F.3d 525 (1st Cir. 2007)).
} 
provisions upholding the application of state laws to subsidiaries, affiliates, and agents of national banks also apply to subsidiaries, affiliates, and agents of federal savings associations. ${ }^{20}$

Section 25(i) codifies the Supreme Court's 2009 decision in Cuomo v. Clearing House, ${ }^{21}$ which upheld the authority of state attorneys general (AGs) to seek judicial enforcement and obtain judicial remedies against national banks for violations of non-preempted state laws. ${ }^{22}$ Section 25(i) also authorizes state AGs to seek judicial enforcement of an applicable federal law "as authorized by such law," as Section 25(i) refers to the enforcement of "applicable law" rather than "applicable State law." ${ }^{23}$ State AGs possess the same judicial enforcement authority against federal savings associations under HOLA. ${ }^{24}$

\section{The OCC has repeatedly failed to comply with Dodd-Frank's preemption framework and other relevant legal authorities.}

The OCC did not comply with Section 25 b when it issued a white paper in December 2016 and a policy statement and licensing manual supplement in July 2018, which asserted that the OCC has authority to approve limited-purpose national bank charters for nondepository "fintech" banks. Those documents did not discuss Section 25b's preemption standards and procedural requirements, even though the OCC's decision to approve such limited-purpose national bank charters would preempt a wide range of state consumer financial laws that apply to nondepository financial services companies. The OCC's white paper contained only a single reference to "the preemption provisions added to the National Bank Act by Dodd-Frank." Neither the white paper nor the policy statement nor the licensing manual supplement explained how the OCC's limited-purpose charter for nondepository fintech banks would comply with Section 25b's "prevents or significantly interferes" preemption standard, its "substantial evidence" requirement, and its "case-by-case" mandate. ${ }^{25}$ In addition, the OCC's limitedpurpose charter documents are unlawful because the OCC does not have statutory authority to issue such a charter. ${ }^{26}$

${ }^{20} 12$ U.S.C. $\S 1465(a),(c) ;$ see also S. Rep. No. 111-176, at 176 (2010): 12 C.F.R. $\S \S 7.4010$ (a) \& 34.6.

${ }^{21}$ Cuomo v. Clearing House Ass'n, L.L.C., 557 U.S. 519 (2009).

2212 U.S.C. $\$ 25 \mathrm{~b}(\mathrm{i})$.

${ }^{23} I d$.

${ }^{24} 12$ U.S.C. $\$ 1465(\mathrm{c})$; see also 12 C.F.R. $\$ 7.4010(\mathrm{~b})$.

${ }^{25}$ OCC, Exploring Special Purpose National Bank Charters for Fintech Companies (Dec. 2016), at 5, available at https://www.occ.gov/publications-and-resources/publications/banker-education/files/exploring-special-purpose-natbank-charters-fintech-companies.html; OCC, Policy Statement on Financial Technology Companies' Eligibility to Apply for National Bank Charters (July 31, 2018), https://www.occ.gov/publications-andresources/publications/comptrollers-licensing-manual/files/considering-charter-apps-from-fin-tech-companies.html; OCC, Comptroller's Licensing Manual Supplement: Considering Charter Applications from Financial Technology Companies (July 2018), https://www.occ.gov/publications-and-resources/publications/comptrollers-licensingmanual/files/considering-charter-apps-from-fin-tech-companies.html.

${ }^{26}$ For analysis showing that the OCC does not have statutory authority to approve limited-purpose national bank charters for nondepository fintech banks, see Arthur E. Wilmarth, Jr., "The OCC's and FDIC's Attempts to Confer Banking Privileges on Nonbanks and Commercial Firms Violate Federal Laws and Are Contrary to Public Policy," 39 Banking \& Financial Services Policy Report No. 10 (Oct. 2020), at 1-7, 17-18, available at http://ssrn.com/abstract=3750964. 
Similarly, the OCC did not comply with Section $25 \mathrm{~b}$ when it issued its "valid when made" rule in June 2020. The OCC claimed that the rule fell "outside of the scope of section $25 \mathrm{~b}$ because of section $25 \mathrm{~b}(\mathrm{f}) . " 27$ That assertion is clearly erroneous. Under 12 U.S.C. $\S 25 \mathrm{~b}(\mathrm{f})$, Section 25b's preemption framework does not affect "the authority conferred by [12 U.S.C. $\S$ 85] for the charging of interest by a national bank" (emphasis added). The OCC's "valid when made" rule does not deal with the "charging of interest by a national bank" but instead seeks to expand Section 85's preemptive scope to cover nonbank purchasers, assignees, and transferees of loans made by national banks. Thus, the OCC's "valid when made" rule extends far beyond the statutory exemption provided by Section $25 \mathrm{~b}(\mathrm{f})$, and the OCC was obligated to comply with Section 25b's preemption standards and procedures before it issued that rule. ${ }^{28}$ In addition, the OCC does not have statutory authority to expand the preemptive scope of 12 U.S.C. $\S 85$ to reach nonbank purchasers, assignees, and transferees of loans made by national banks. ${ }^{29}$

On December 18, 2020, the OCC issued Interpretive Letter 1173 (IL 1173), which explains how the OCC "interprets" the preemption standards and procedural requirements of Section $25 \mathrm{~b} .^{30}$ IL 1173 presents two legal conclusions that are contrary to the express terms and clear purposes of Section 25b. First, IL 1173 asserts that an action by the OCC that has the practical effect of preempting state consumer financial laws is not subject to the requirements of Section 25b unless the OCC's action is a "preemptive determination" contained in a "regulation or order." According to IL 1173, the OCC does not make a "preemption determination" subject to Section 25b if the OCC takes an "action that has only indirect or incidental effects on state consumer financial laws." 31

As explained in a brief filed by a group of state AGs in a pending lawsuit, the OCC's erroneous claim in IL 1173 would allow the OCC to take a wide variety of actions preempting state consumer financial laws while evading Section 25b's preemption standards and procedural requirements. For example, the OCC could issue a policy statement approving a new type of national bank charter, or it could issue a letter "interpreting" the NBA in a way that allows national banks to engage in a new activity. Either action would be highly likely to have a preemptive impact on state consumer financial laws. Under IL 1173, neither action would be

${ }^{27}$ OCC final rule, "Permissible Interest on Loans That Are Sold, Assigned or Otherwise Transferred," 85 Fed. Reg. 33530, 33533 (June 2, 2020) (citing 12 U.S.C. § 25b(f)).

${ }^{28}$ See Arguments, Part I and II, in Plaintiffs' Opposition to Defendants' Cross-Motion for Summary Judgment and Reply in Support of Plaintiffs' Motion for Summary Judgment, in People v. OCC, No. 4:20-CV-05200-JSW (N.D. Cal., filed February 11,2021) (brief filed by group of state AGs in a case challenging the validity of the OCC's "valid when made" rule) [hereinafter Brief of State Attorneys General], available on Westlaw at 2021 WL 1341192; S. Rep. No. 111-176, at 176 (2010) (Section 25b "does not alter or affect existing laws regarding the charging of interest by national banks") (emphasis added); Arthur E. Wilmarth, Jr., "Comment Letter in Opposition to the OCC's Proposed 'Valid-When-Made' Rule" (Jan. 17, 2020) [hereinafter Wilmarth Comment Letter on OCC's Valid-When-Made Rule], at 3-4, 7-13, available at http://ssrn.com/abstract=3523939.

${ }^{29}$ For analysis showing that the OCC's "valid when made" rule exceeds the OCC's statutory authority and is unlawful, see Brief of State Attorneys General, supra note 28; Adam J. Levitin, "Spurious Pedigree of the ValidWhen-Made Doctrine," 71 Duke Law Journal Online (2022) (forthcoming) (draft of July 16, 2021), at 20 (maintaining that the "valid-when-made" doctrine - on which the OCC's rule relies - is a "modern invention, fabricated by attorneys for financial services trade associations, ... [and] is not valid, but made up"), available at http://ssrn.com/abstract=3888386; Wilmarth Comment Letter on OCC's Valid-When-Made Rule, supra note 28.

30 "OCC Chief Counsel's Interpretation: 12 U.S.C. $§ 25$ " (Dec. 18, 2020), OCC Interpretive Letter 1173 [hereinafter IL 1173], https://www.occ.gov/news-issuances/news-releases/2020/nr-occ-2020-176a.pdf.

${ }^{31}$ IL 1173, supra note 30 , at 3. 
subject to Section 25b's preemption standards and procedural requirements as long as the OCC did not take that action in the form of a regulation or order. IL 1173's "interpretation" of Section $25 \mathrm{~b}$ is untenable because it "would leave the applicability of Section 25b's safeguards in the hands of the OCC" and "pervert the purpose of $\S 25 \mathrm{~b}$, which was enacted to constrain the OCC's ability to preempt state law." 32

Second, IL 1173 contends that "the OCC generally receives Chevron deference for any interpretation of federal law concluding that a particular national bank power is authorized by [the NBA] or [12 U.S.C.] section 371." IL 1173 also argues that the lower level of Skidmore deference mandated by Section 25b(b)(5)(A) applies only if the OCC expresses a "conclusion that these federal laws preempt state law."33 The foregoing claims contravene the express terms of Section $25 b(b)(5)(A)$, which provide that the OCC receives the lower level of Skidmore deference for "any determinations made by the Comptroller regarding preemption of a State law by [the NBA or 12 U.S.C. $\S 371$ ]." ${ }^{34}$ The broad language of the operative clause in Section $25 \mathrm{~b}(\mathrm{~b})(5)(\mathrm{A})$ - "any determinations made by the Comptroller regarding preemption" - makes clear that the lower level of Skidmore deference applies to all OCC actions that have the practical effect of preempting state law, whether or not the OCC's actions include a formal "conclusion" that state law is preempted. That conclusion is further supported by Cuomo and Hymes.

In Cuomo, the Supreme Court rejected the argument that an OCC rule was not a preemptive action because it "merely "interpret[s]" a federal statute that itself preempts state law - 12 U.S.C. $§ 484(a)$. The Supreme Court held that any "interpretation" by the OCC that expands the preemptive scope of a federal statute is unquestionably a preemptive agency action. As the Court explained, if an OCC "interpretation" expanding the preemptive scope of a federal statute "is not pre-emption, nothing is." 35

In Hymes, the district court held that all of the OCC's "views on NBA preemption" receive the lower level of Skidmore deference. The OCC's "view" on preemption considered in Hymes was set forth in an amicus brief, which presented the OCC's "interpretation" of the scope of one of the agency's preemptive regulations. The district court held that the "interpretation" in the amicus brief of the scope of the OCC's preemptive regulation was entitled to receive only Skidmore deference. ${ }^{36}$ Thus, Cuomo and Hymes confirm the conclusion that is strongly indicated by the express terms of Section $25 b(b)(5)(A)$ - namely, that any action by the OCC that has the practical effect of expanding the scope of preemption of state consumer financial laws will receive only Skidmore deference. Both decisions refute the OCC's claim in IL 1173 that the

\footnotetext{
${ }^{32}$ Brief of State Attorneys General, supra note 28 (Argument, Part I.A.2) (citing and quoting Am. Civil Liberties Union v. FCC, 823 F.2d 1554, 1567 n.32 (D.C. Cir. 1987) (“[I]t seems highly unlikely that a responsible Congress would implicitly delegate to an agency the power to define the scope of its own power.").

${ }^{33}$ IL 1173 , supra note 30 , at 5-6.

${ }^{34} 12$ U.S.C. $\$ 25 \mathrm{~b}(\mathrm{~b})(5)(\mathrm{A})$.

${ }^{35}$ Cuomo, 557 U.S. at 535.

${ }^{36}$ Hymes, 408 F. Supp. 3d at 192-93 ("And when it comes to the OCC in particular, Congress has made it abundantly clear that courts are not to give any heightened deference to the agency's views on NBA preemption. See 12 U.S.C. $\$ 25 \mathrm{~b}(\mathrm{~b})(5)(\mathrm{A}) \ldots$... Accordingly, the OCC's amicus brief is relevant here only to the extent it is persuasive").
} 
agency must issue a formal "conclusion" about preemption in order to trigger the lower level of Skidmore deference required by Section $25 \mathrm{~b}(\mathrm{~b})(5)(\mathrm{A}) .^{37}$

The OCC's actions described above are recent examples of the agency's repeated failures to comply with Section 25b. When Congress passed Dodd-Frank in 2010, it rejected the blanket preemption rules that the OCC issued in 2004. The Senate committee report explained that, under Section $25 \mathrm{~b}$, "[ $\mathrm{t}]$ he standard for preempting State consumer financial law would return to what it had been for decades, those recognized by the Supreme Court in Barnett Bank v. Nelson, 517 U.S. 25 (1996) (Barnett), undoing broader standards adopted by rules, orders, and interpretations issued by the OCC in 2004." 38 The Senate committee report strongly criticized the OCC's preemptive actions in 2004 and concluded that the OCC "actively created an environment where abusive mortgage lending could flourish without State controls." 39

In 2011, the OCC revised several of its preemption rules, ostensibly to bring them into conformity with Section $25 \mathrm{~b} .{ }^{40}$ However, the OCC's revised rules do not include the "prevent or significantly interfere" preemption standard established by Barnett Bank, despite Congress's express codification of that standard in Section 25b(b)(1)(B). In defiance of Congress's explicit mandate, the OCC asserted that "the Dodd-Frank Act does not create a new stand-alone 'prevents or significantly interferes' preemption standard." 41 The legislative history of DoddFrank and subsequent court decisions confirm that Congress intended to require the OCC to follow Barnett Bank's "prevent or significantly interfere" preemption standard by expressly codifying that standard in Section $25(\mathrm{~b})(\mathrm{B})(1)(\mathrm{B}) .^{42}$

In addition, three of the revised preemption rules that the OCC issued in $2011-12$ C.F.R. $\S \S 7.4007,7.4008$, and 34.4 - continue to declare that broad categories of state laws are preempted across the nation. When the OCC issued those sweeping and categorical preemption rules in 2011, the OCC did not comply with Section 25b's "substantial evidence" and "case-bycase" requirements (including the requirement to consult with the CFPB). Instead, the OCC claimed that it did not need to comply with Section $25 \mathrm{~b}$ 's requirements because its blanket preemption rules were derived from the OCC's 2004 rules. The OCC asserted, without any supporting authority, that its "regulations in effect prior to the effective date [of Dodd-Frank] are

\footnotetext{
${ }^{37}$ See Brief of State Attorneys General, supra note 28 (Argument, Parts I.A.2 and II.A).

${ }^{38}$ S. Rep. No. 111-176, at 175-76 (2010) (emphasis added); see also Elosta, supra note 7, at 1298-1300; Wilmarth, "Dodd-Frank," supra note 7, at 936-37.

${ }^{39}$ S. Rep. No. 111-176, at 16-17 (2010). For further analysis of the OCC's woeful record of regulatory laxity and unwarranted preemption of state consumer protection laws and state enforcement efforts during the 1990s and 2000s, see id. at 10-18; Wilmarth, "Dodd-Frank," supra note 7, at 897-98, 901-19.

${ }^{40}$ OCC, "Office of Thrift Supervision Integration; Dodd-Frank Act Implementation,” 76 Fed. Reg. 43549 (July 21 , 2011) [hereinafter OCC's 2011 Preemption Rules].

${ }^{41} I d$. at 43555.

${ }^{42}$ H.R. Rep. No. 111-517, at 875 (2010) (Conf. Rep.), reprinted in 2010 U.S.C.C.A.N. 722 , 731 (stating that Section $25 \mathrm{~b}$ "revises the standard the OCC will use to preempt state consumer protection laws. It codifies the standard in the 1996 Supreme Court case [of] Barnett Bank.”) (emphasis added); S. Rep. No. 111-176, at 175-76 (2010) (explaining that, under Section 25b, "[t] he standard for preempting State consumer financial law would return to what it had been for decades, those recognized by the Supreme Court in Barnett Bank v. Nelson, ... [T] by the Supreme Court in Barnett [is] "prevents or significantly interferes with a national bank's exercise of its power"); supra note 5 and accompanying text (citing court decisions affirming that "prevents or significantly interferes" is the controlling preemption standard under Section 25b).
} 
not subject to the case-by-case requirement." 43 Three federal courts subsequently determined that the OCC's 2011 preemption rules "are entitled to little if any deference" because the OCC "largely reaffirmed its previous preemption conclusions without further analysis under the Barnett Bank standard," 44 and without attempting to comply with Section 25b's "substantial evidence" and "case-by-case" requirements. ${ }^{45}$

The OCC's assertion that its 2004 rules remained valid after Dodd-Frank - even though they did not comply with Section 25b's requirements - is untenable. Under Section 25b(b)(1), state consumer financial laws are preempted by the NBA "only if" a federal agency or court makes a preemption determination in compliance with all of the requirements of Section $25 \mathrm{~b}$. Section 1043 of Dodd-Frank provides a very limited exception to that mandate. Section 1043 preserves the application of previous OCC regulations and orders to "any contract entered into [by a national bank or its subsidiary] before July 21, 2010" (the date of Dodd-Frank's enactment). ${ }^{46}$ Congress intended that Section 1043 would "provide stability to existing contracts" - those entered into before Dodd-Frank's enactment - by allowing those contracts to be governed by the OCC's preexisting rules and orders. ${ }^{47}$

Section 1043's carefully limited exception reveals Congress's unmistakable intention that the OCC's preexisting preemption rules and orders would not apply to transactions by national banks after July 21, 2010, unless the OCC revised those rules and orders to bring them into full compliance with Section 25b. The OCC's claim that its 2004 preemption rules remain valid for new transactions after 2010 would render Section 1043 "meaningless, in violation of the 'endlessly repeated principle of statutory construction ... that all words in a statute are to be assigned meaning, and that nothing therein is to be construed as surplusage." 48 Accordingly, the OCC violated Section 25b when it issued three blanket preemption rules in $2011-12$ C.F.R. $\S \S$ 7.4007, 7.4008, and 34.4 - that do not comply with Section 25b's "prevents or significantly interferes" preemption standard, its "case-by-case" requirement, and its "substantial evidence" mandate. ${ }^{49}$

\footnotetext{
${ }^{43}$ OCC's 2011 Preemption Rules, supra note 40, 76 Fed. Reg. at 43553, 43557 (quote).

${ }^{44}$ Lusnak, 883 F.3d at 1193-94.

${ }^{45}$ Hymes, 408 F. Supp. 3d at 180, 185, 191 (concluding that the OCC's 2011 preemption rules are "entitled to little if any deference" because "the agency failed to revise them after Dodd-Frank repudiated the agency's approach to preemption"); Clark, supra note 5, at *4-*5 (holding that one of the OCC's 2011 preemption rules, 12 C.F.R. § 34.4, is "entitled to minimal deference" because the OCC in 2011 "determined that the agency was not bound by Congress's mandate to review state consumer protection laws on a 'case-by-case' basis" and also "did not engage in a substantive reevaluation of preemption, in light of Dodd-Frank").

${ }^{46}$ Pub. L. No. 111-203, § 1043, 124 Stat. 2014 (2010) (codified at 12 U.S.C. § 5553) (emphasis added).

${ }^{47}$ S. Rep. No. 111-176, at 175 (2010).

${ }^{48}$ Independent Ins. Agents of America, Inc. v. Hawke, 211 F.3d 638, 643-44 (2000) (quoting Qi-Zhou v. Meissner, 70 F.3d 136, 139 (D.C. Cir. 1995)); see also Wilmarth, "Dodd-Frank," supra note 7, at 939-40.

${ }^{49}$ See supra notes 44-45 and accompanying text (discussing the strong criticisms of the OCC's 2011 revised preemption rules by the courts in Lusnak, Hymes, and Clark). See also Arthur E. Wilmarth, Jr., "OCC Gets It Wrong on Preemption, Again," American Banker (July 29, 2011), at 8, available on Westlaw at 2011 WLNR 14961080; Arthur E. Wilmarth, Jr., "The Financial Industry's Misguided Quest to Undermine the Consumer Financial Protection Bureau," 31 Review of Banking \& Financial Law 881, 914-16 (2012), available at http://ssrn.com/abstract=1982149.
} 
In addition, the OCC's 2001 preemption rule on non-interest charges and fees does not comply with Section 25b. The 2001 rule states that " $\mathrm{t}] \mathrm{h}$. OCC applies preemption principles derived from the United States Constitution, as interpreted through judicial precedent, when determining whether State laws apply that purport to limit or prohibit charges and fees described in this section." The 2001 rule does not include any reference to the "prevents or significantly interferes" preemption standard mandated by Section $25 \mathrm{~b}(\mathrm{~b})(1)(\mathrm{B}) .^{50}$

The OCC has also failed to comply with Section $25 \mathrm{~b}(\mathrm{~d})$. That provision requires the OCC to "periodically conduct a review, though notice and public comment, of each determination that a provision of Federal law preempts a State consumer financial law," within five years after issuing that determination. After completing a preemption review, the OCC must issue a public notice describing the results of that review, and the OCC must also submit a report to the House Financial Services Committee and the Senate Committee on Banking, Housing, and Urban Affairs. The required public notice and congressional report must specify whether the OCC intends to continue, rescind, or amend each preemption determination that it reviews. ${ }^{51}$

The OCC has not conducted any preemption reviews pursuant to Section $25 \mathrm{~b}(\mathrm{~d})$, even though the OCC's most important preemption rules were issued more than a decade ago, in July $2011 .^{52}$ Several of the OCC's other preemption rules are more than fifteen years old, and the OCC has not performed any preemption reviews of those rules. ${ }^{53}$ The OCC's repeated failures to comply with Section $25 \mathrm{~b}$ bring to mind the strong admonition that the agency received from the Supreme Court in a 1966 decision. In that case, the Supreme Court warned the OCC that it cannot "pick and choose what portion of the law binds [it]." 54

\section{General state laws continue to apply to national banks and are governed by Barnett Bank's "prevent or significantly interfere" preemption standard.}

Dodd-Frank's preemption standards and procedural requirements apply to "State consumer financial laws" and do not refer to state laws of general application. In contrast, as discussed above, Sections $25 \mathrm{~b}(\mathrm{~b})(2)$ and $25(\mathrm{~h})$ provide that the NBA and 12 U.S.C. $\$ 371$ do not have any preemptive effect on all types of state laws that apply to nonbank subsidiaries, affiliates and agents of national banks. The references to general state laws in Sections 25b(b)(2) and 25(h) are understandable because Congress intended to protect all types of state laws from claims of preemption under the NBA and Section 371 regarding entities that are not national banks. ${ }^{55}$

The Senate committee report on Dodd-Frank expressly confirms what Section 25b's relative silence about general state laws implies - namely, that Section 25b's preemption provisions for "state consumer financial laws" do not affect the application of general state laws

\footnotetext{
5012 C.F.R. $\$ 7.4002(\mathrm{~d})$.

51 U.S.C. $\$ 25 b(d)$.

${ }^{52}$ See supra notes 40-49 and accompanying text.

${ }^{53}$ See, e.g., 12 C.F.R. $\$ \S 7.4002(\mathrm{~d}), 7.4003,7.4004,7.4005,34.5$ \& 37.1(c).

${ }^{54}$ First National Bank of Logan v. Walker Bank \& Trust Co., 385 U.S. 252, 261 (1966).

55 See supra notes 14-16, 18-19, and accompanying text (discussing 12 U.S.C. $\S \S 25 b(b)(2) \&(h)$ ).
} 
to national banks and federal savings associations. ${ }^{56}$ Two judicial canons of statutory construction strongly support the presumptive application of general state laws to national banks. First, when interpreting a "federal statutory scheme that is comprehensive and detailed" the Supreme Court has said that "matters left unaddressed in such a scheme are presumably left subject to the disposition provided by state law." 57

Second, the Supreme Court has held that "Congress is presumed to be aware of an administrative or judicial interpretation of a statute and to adopt that interpretation when it reenacts a statute without change." 58 Section $25 \mathrm{~b}$ did not change any provision of the NBA dealing with the application of general state laws to national banks. Accordingly, Section 25b should be construed in harmony with the following Supreme Court decisions, which predated Dodd-Frank and upheld the application of general state laws to national banks.

In Cuomo v. Clearing House, L.L.C., ${ }^{59}$ the Supreme Court declared that "States . . have always enforced their general laws against national banks - and have enforced their bankingrelated laws against national banks for at least 85 years, as evidenced by [First National Bank in] St. Louis [v. Missouri, 263 U.S. 640 (1924)], in which we upheld enforcement of a state antibank-branching law." 60 Thus, Cuomo affirmed the applicability of "general [state] laws" to national banks. ${ }^{61}$ Congress was aware of - and approved - the Supreme Court's decision in Cuomo when Congress enacted Section 25b in 2010. In Section 25b(i), as discussed above, Congress codified Cuomo's holding that state AGs have authority to bring judicial actions against national banks to enforce non-preempted state laws. ${ }^{62}$

The St. Louis decision - which Cuomo endorsed - also affirms the presumptive application of general state laws to national banks. St. Louis held that, under the NBA, "the rule [is] the operation of general state laws upon the dealings and contracts of national banks," while preemption of such laws is an "exception" that applies only when those laws "expressly conflict with the laws of the United States or frustrate the purpose for which national banks were created, or impair their efficiency to discharge the duties imposed upon them by the law of the United States." "63 Cuomo and St. Louis are both in harmony with Atherton v. FDIC, ${ }^{64}$ which declared that "federally chartered banks are subject to state law." 65 As support for that principle, Atherton cited and quoted previous Supreme Court decisions dating back to National Bank v.

Commonwealth $^{66}$ - an 1870 case that was decided less than a decade after the NBA's enactment. In Commonwealth, the Supreme Court declared that national banks

\footnotetext{
${ }^{56}$ S. Rep. No. 111-176, at 175 (2010) (stating that Dodd-Frank's new preemption framework for national banks and federal savings associations "does not alter the preemption standards for State laws of general applicability to business conduct").

${ }^{57}$ O’Melveny \& Myers v. FDIC, 512 U.S. 79, 85 (1994).

${ }^{58}$ Forest Grove School Dist. v. T.A., 557 U.S. 230, 239 (2009) (quoting Lorillard v. Pons, 434 U.S. 575, 580 (1978)).

${ }^{59} 557$ U.S. 519 (2009).

${ }^{60} I d$. at 534.

${ }^{61} \mathrm{Id}$.

${ }^{62} 12$ U.S.C. § 25b(i); see supra notes 21-22 and accompanying text.

${ }^{63}$ St. Louis, 263 U.S. at 656 (quoting McClellan v. Chipman, 164 U.S. 347, 357 (1896)).

${ }^{64} 519$ U.S. 213 (1997).

${ }^{65} \mathrm{Id}$. at 222.

6676 U.S. (9 Wall.) 353 (1870).
} 
are subject to the laws of the State, and are governed in their daily course of business far more by the laws of the State than of the nation. All their contracts are governed and construed by State laws. Their acquisition and transfer of property, their right to collect their debts, and their liability to be sued for debts, are all based on State law. It is only when State law incapacitates the [national] banks from discharging their duties to the federal government that it becomes unconstitutional. ${ }^{67}$

Thus, Commonwealth upheld the applicability of general state laws to national banks unless such laws "incapacitate[d]" national banks from fulfilling their "duties" to the United States. Under the NBA as originally enacted in 1863 and amended in 1864, the "duties" of national banks to the federal government were (i) to issue a national currency in the form of national bank notes, and (ii) to purchase and deposit Treasury bonds with the United States Treasury to ensure the payment of those notes. ${ }^{68}$ Those "duties" were phased out after Congress passed the Federal Reserve Act in 1913, and national banks stopped issuing national bank notes by $1935 .{ }^{69}$ Accordingly, the "duties" referred to in Commonwealth are no longer relevant, and the reasoning in Commonwealth supports the application of general state laws to national banks in the absence of a direct and irreconcilable conflict with federal law. ${ }^{70}$

Commonwealth's holding that state laws generally control the "right [of national banks] to collect their debts" as well as "their contracts" and "[t]heir acquisition and transfer of property" was quoted with approval in McClellan v. Chipman..$^{71}$ McClellan held that a national bank must comply with a Massachusetts statute that prohibited any transfer of property by an insolvent debtor "with a view to give a preference to a creditor or person who has a claim against him."72 McClellan upheld the state statute's application to national banks even though the state law imposed a limitation on the express power of national banks, under 12 U.S.C. § 29, to accept transfers of real property in satisfaction of debts previously contracted. The Supreme Court explained:

No function of [national] banks is destroyed or hampered by allowing the banks to exercise the power to take real estate, provided only they do so under the same conditions and restrictions to which all the other citizens of the State are subjected, one of which limitations arises from the provisions of the state law which in case of insolvency seeks to forbid preferences between creditors. ${ }^{73}$

67 Atherton, 519 U.S. at 222-23 (quoting Commonwealth, 76 U.S. (9 Wall.) at 362).

68 Tiffany v. Nat'l Bank of Missouri, 85 U.S. 409, 413 (1874) (explaining that national banks were "established for the purpose, in part, of providing a currency for the whole country, and in part to create a market for the loans of the General government'); see also First Agricultural Nat'l Bank v. State Tax Comm 'n, 392 U.S. 339, 355-56 (1968) (Marshall, J., dissenting) (discussing the same original purposes for which Congress created national banks).

${ }^{69}$ First Agricultural Nat'l Bank, 392 U.S. at 356-58 (Marshall, J., dissenting).

${ }^{70}$ See Commonwealth, 76 U.S. (9 Wall.) at 362; St. Louis, 263 U.S. at 656.

${ }^{71} 164$ U.S. 347, 357 (1896).

${ }^{72} \mathrm{Id}$. at 348 (quoting Mass. statute).

${ }^{73} I d$. at 358 . 
The Court in McClellan found "no conflict between the special power conferred by Congress upon national banks to take real estate for certain purposes, and the general and undiscriminating law of the State of Massachusetts subjecting the taking of real estate to certain restrictions, in order to prevent preferences in cases of insolvency.",74

Similarly, in Anderson National Bank v. Luckett,${ }^{75}$ the Supreme Court held that national banks must comply with a Kentucky statute that required all banks to transfer dormant deposit accounts to state authorities for a determination of whether such accounts had been abandoned and should be escheated to the state. A national bank, supported by the OCC as amicus curiae, challenged the Kentucky statute on grounds of preemption. The Supreme Court rejected the bank's preemption claim, declaring that "the mere fact that the depositor's account is in a national bank does not render it immune to attachment by creditors of the depositor, as authorized by state law." 76 The Court further explained that

a bank account is ... part of the mass of property within the state whose transfer and control is subject to state control.... It has never been suggested that nondiscriminatory laws of this type are so burdensome as to be inapplicable to the accounts of depositors in national banks. ${ }^{77}$

Luckett made clear that the power of national banks to accept deposits is subject to general, nondiscriminatory state laws governing contract rights and creditors' rights with respect to personal property, including deposit accounts. In that regard, the Supreme Court held that

an inseparable incident of a national bank's privilege of receiving deposits is its obligation to pay them to the persons entitled to demand payment according to the law of the state where it does business. A demand for payment of an account by one entitled to make the demand does not infringe or interfere with any authorized function of the bank. ${ }^{78}$

As indicated above, Section $25 \mathrm{~b}$ does not address the application of general state laws to national banks. Congress's silence on that topic should be construed as an implicit affirmation of the decisions in Cuomo, St. Louis, Commonwealth, McClellan, Luckett and Atherton - all of which upheld the presumptive application of general state laws to national banks. As the Supreme Court explained in Lorillard v. Pons, ${ }^{79}$ "where, as here, Congress adopts a new law incorporating sections of a prior law, Congress normally can be presumed to have had knowledge of the interpretation given to the incorporated law, at least insofar as it affects the new statute. $" 80$

${ }^{74} I d$. at $359,361$.

75321 U.S. 233 (1948),

${ }^{76} I d$. at 248.

${ }^{77}$ Id. (citations omitted).

${ }^{78}$ Id. at $248-49$.

79434 U.S. 575 (1978).

${ }^{80} \mathrm{Id}$. at 581; see also Commissioner v. Engle, 464 U.S. 206, 225 (1984) (construing a federal tax statute in harmony with prior Supreme Court decisions because Congress did not "explicitly" indicate its disagreement with those decisions when Congress amended the statute). 
Accordingly, Section 25b should be interpreted as affirming the foregoing Supreme Court decisions, which upheld the application of general state laws to national banks in the absence of a direct and irreconcilable conflict with federal law. Such an interpretation is particularly warranted in view of Section 25b(i)'s express incorporation of the Supreme Court's decision in Cuomo. In determining whether a general state law creates an "irreconcilable conflict" with federal law, Barnett Bank held that the controlling question is whether the state law would "prevent or significantly interfere with the national bank's exercise of its powers." 11

Based on the foregoing Supreme Court decisions and Section 25b(B)(1)(B), courts and the OCC should apply Barnett Bank's "prevent or significantly interfere" preemption standard in all cases involving claims that state laws are preempted by a federal law authorizing a national bank power, whether those cases involve general state laws or state consumer financial laws. As shown above, Congress endorsed Barnett Bank's "prevent or significantly interfere" preemption standard by codifying it in Section $25 \mathrm{~b}(\mathrm{~b})(1)(\mathrm{B}) .{ }^{82}$

As revised in 2011, the OCC's preemption rules for deposit-taking, lending without real estate security, and real estate lending acknowledge that general state laws apply to those activities by national banks "to the extent consistent with the decision of the Supreme Court in Barnett Bank." 83 However, those regulations do not refer specifically to the "prevent or significantly interfere" preemption standard established by Barnett Bank. Similarly, the OCC's 2001 preemption rule for non-interest charges and fees does not refer to Barnett Bank's "prevent or significantly interfere" preemption standard. ${ }^{84}$ The foregoing regulations therefore do not conform to the controlling preemption standard mandated by Barnett Bank.

\section{Conclusion}

For the reasons set forth above, several of the OCC's existing rules, policies, and legal interpretations do not comply with 12 U.S.C. $\$ 25 \mathrm{~b}$ and other legal authorities governing the scope of preemption for national banks and federal savings associations. The OCC should promptly take the following steps to achieve compliance with those authorities:

(A) The OCC should rescind its 2016 white paper and its 2018 policy statement and licensing manual supplement, which erroneously and unlawfully assert that the OCC has authority to create a limited-purpose charter for nondepository fintech national banks.

(B) The OCC should rescind its unlawful "valid when made" rule.

\footnotetext{
${ }^{81}$ Barnett Bank, 517 U.S. at 31 ("In this case we must ask whether the Federal and State Statutes are in "irreconcilable conflict." ); id. at 33-34 (adopting the "prevent or significantly interfere" preemption standard and citing Luckett, McClellan v. Chipman, and Commonwealth in support of that standard).

${ }^{82}$ See supra notes 4-5, 41-42 and accompanying text.

${ }^{83} 12$ C.F.R. $\S \S 7.4007$ (c), 7.4008(e) \& 34.4(b).

${ }^{84}$ See supra notes 41,50 and accompanying text.
} 
(C) The OCC should revise 12 C.F.R. $§ \S 7.4002,7.4007,7.4008$, and 34.4 to bring them into full compliance with Section 25b's preemption framework, including the "prevents or significantly interferes" standard established by Barnett Bank and Section 25b(b)(1)(B), as well as Section 25b's procedural requirements (including the substantial evidence and case-by-case mandates).

(D) The OCC should conduct preemption reviews of all of its other preemption rules, orders, and other determinations as required by Section $25 \mathrm{~b}(\mathrm{~d})$.

(E) The OCC should rescind its erroneous and unlawful Interpretive Letter 1173. 